\title{
Three cases of hematologic malignancies in pregnancy: Still difficult to diagnose and hard to treat
}

\section{Gebelikte hematolojik maligniteli ücç olgu; hala teşhis zor ve tedavi etmek zor}

Özlem Bozoklu Akkar'1, Hatice Terzi ${ }^{2}$, Savaş Karakuş ${ }^{1}$, Çaglar Yıldız ${ }^{1}$, İsmail Akkar ${ }^{3}$, Mehmet Şencan², Fatih Bolat ${ }^{4}$, Meral Çetinn ${ }^{1}$

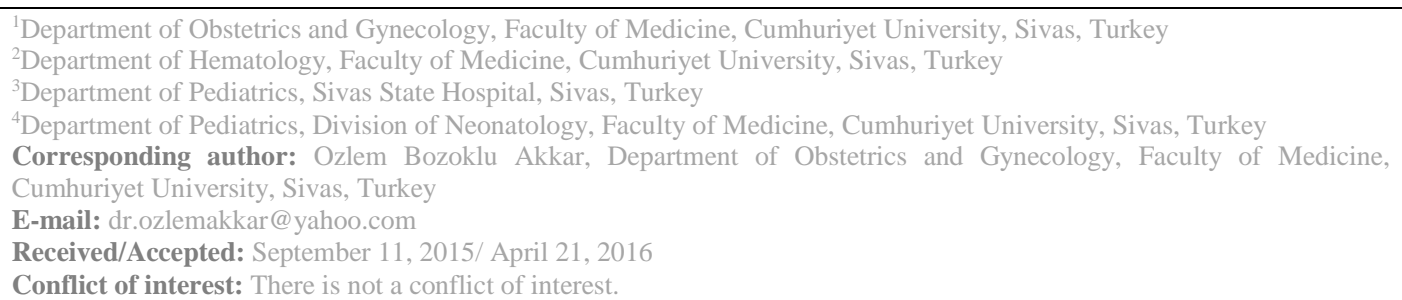

\section{SUMMARY}

The hematologic malignancies during pregnancy are rare and there is often a delay in diagnosis because of the similarity of symptoms to those of pregnancy. Therefore the management of disease necessitates many medical, psychological, social, and ethical problems for the patient and physician to deal with and a multidisciplinary approach of a medical team consisting of hematologist, obstetrician and pediatrician. Here, we present three cases of hematologic malignancies during pregnancy; acute myeloid leukemia, acute lymphoblastic leukemia, and Bcell non-Hodgkin's lymphoma that were admitted to our clinic with different clinical presentation. There is a need for measures to increase the awareness of health workers related to hematologic malignancies during antenatal care.

Keywords: Pregnancy, acute myeloid leukemia, acute lymphoblastic leukemia, non-Hodgkin's lymphoma

\section{ÖZET}

Gebelik süresince hematolojik maligniteler nadirdir ve gebelik semptomları ile benzer olduğundan dolayı sıklıkla tanıda bir gecikme vardır. Bu yüzden, hasta ve hekim için bir çok medikal, psikolojik, sosyal ve etik problemler ile başa çıkmak için hematoloji, kadın doğum ve pediatri uzmanlarını içeren medikal bir takımın multidisipliner yaklaşımına gereksinim vardır. Burada gebeliği boyunca hematolojik malignite tanısı almış üç vakayı sunduk; faklı klinik tablo ile kliniğimize kabul ettiğimiz akut myeloid lösemi, akut lenfoblastik lösemi ve b hücreli nonhodgkin lenfoma. Doğum öncesi dönem süresince hematolojik malignitelerde ilgili sağlık çalışanlarının farkındalığını artırmak için önlemlere ihtiyaç vardır.

Anahtar sözcükler: Gebelik, akut myeloid lösemi, akut lenfoblastik lösemi, non-hodgkin lenfoma 


\section{INTRODUCTION}

The hematologic malignancies during pregnancy are uncommon. The diagnosis is often late because of the resemblance of symptoms to those of pregnancy and the avoidance of imaging studies during pregnancy. Therefore the management of disease and both of fetal and maternal outcome are usually affected that causes many difficulties for the patient and doctor ${ }^{1,2}$.For the pregnant woman, the treatment of hematologic malignancies in pregnancy creates a dilemma related to her life and fate of her fetus, so it also makes the disease more complicated to manage for the physicians.

In this article, we present three cases of hematologic malignancy in pregnancy to increase the awareness of health workers for the differentiation of clinical findings of hematologic malignancies from common complaints of pregnant women.

\section{Case 1}

Twenty-one-year-old woman at 18 weeks gestation was admitted to emergency service with symptoms of fatigue, nausea, and vomiting. On physical and obstetrical examination there was the pallor of skin and mucosal surfaces, and 18 weeks of normal pregnancy. The blood tests revealed pancytopenia, bone marrow aspiration was performed and she was diagnosed as acute myeloid leukemia. She did not accept to terminate her pregnancy, and she was treated with CytarabineIdarabucin as a remission-induction therapy. She presented to the emergency service with the symptom of abdominal pain at 25 weeks gestation. After evaluation, 20 weeks of intrauterine ex fetus was determined. Medical abortion with dilatation and curettage due to rest placenta were performed. On August 2009 the patient was received first consolidation therapy with high dose Ara-C (HIDAC; Cytarabine 2x2 g/m2 on days 1,3, and 5). Since the result of bone marrow aspiration in was remission, on October 2009, second consolidation therapy (HIDAC) was performed, after that the result of bone marrow aspiration was $<5 \%$ blast with the remission of the disease. Third and fourth HIDAC consolidation therapies were performed, and on February 2010 the allogeneic stem cell transplantation was executed. After the transplantation, the patient had the symptoms of dizziness and syncope, the cranial computed tomography showed subdural hematoma. The craniotomy, drainage of the hematoma, and biopsy of the bone tissue were performed by the neurosurgeon. The result of the biopsy was the relapse of the acute myeloid leukemia.Afterwards, the patient was managed with cranial radiotherapy and high dose Cytarabine. The patient referred to the emergency service with widespread bone pain and weakness on March 2011, and more than $90 \%$ blast was determined with the bone marrow aspiration, therefore the patient was accepted as relapse-refractory acute myeloid leukemia so she was treated with rescue protocol of FLAGIDA(Fludarabine + Cytarabine +Idarabucin + G-CSF) chemotherapy. But, she did not undergo to the remission. As a second rescue protocol EMA (Etoposide+ Mitoxantrone+ Cytarabine) was used to treat the patient during that she had a respiratory distress, with her thorax computed tomography showing widespread lung metastasis of acute myeloid leukemia. She died due to respiratory distress and cardiopulmonary arrest (Table 1).

\section{Case 2}

In 2012, the patient was diagnosed as acute lymphoblastic leukemia. She was managed with 4 cycles of HyperCVAD (Vincristine + Cyclophosphamide + Cytarabine + Methotrexate + Dexamethasone + Doxorubicin) and afterwards, she went into remission. She admitted to the emergency service with symptoms of fatigue, abdominal distension, and amenorrhea in June 2013. After physical and radiological evaluation, 24 weeks of gestation was determined. The bone marrow aspirate and flow cytometry was performed and the recurrence of Philadelphia (+) acute 
lymphoblastic leukemia was determined. She was managed with Dasatinib + FLAG-IDA protocol. During the management and follow-up, she had a complaint of uterine contractions and vaginal bleeding. After obstetrical examination, the regular uterine contractions and vaginal bleeding due to cervical dilatation of $5 \mathrm{~cm}$ were determined, and a male infant weighing $1050 \mathrm{~g}$ was delivered vaginally with Apgar scores of 5 at 1 minute and 7 at 5 minutes.The patient developed sepsis due to neutropenia. She died due to sepsis at the postpartum third day (Table 1). The neonate was diagnosed as pancytopenia in the first 1 to 2 hours after delivery based on the following laboratory findings: hemoglobin: $10.6 \mathrm{~g}$ dl; white blood cell count: 530/mm3; platelet count: $11.000 / \mathrm{mm} 3$. On the first day of hospitalization, the platelet and erythrocyte transfusion were given. $\mathrm{He}$ showed severe neutropenia, with an absolute neutrophil count of 100 and 40/mm3, respectively. Granulocyte colony stimulating factor was initiated on the third day of life. This treatment was continued until the neutrophil count reached $1500 / \mathrm{mm}^{3}$. He was discharged with the diagnosis of mild bronchopulmonary dysplasia at 36 weeks of postmenstrual age.

\section{Case 3}

39-year-old woman was admitted to the emergency service with the complaints of sweating and abdominal pain. Her physical and radiological evaluation revealed 34 weeks of gestational age of pregnancy, hepatosplenomegaly and disseminated lymphadenopathy. The blood tests, bone marrow aspiration, and flow cytometry confirmed the diagnosis of B-cell non-Hodgkin's lymphoma. During her follow-up, the uterine contractions started and a female infant weighing 2200g with Apgar scores of 6 at 1 minute and 8 at 5 minutes was delivered with Cesarean section because of a previous Cesarean delivery. At the postpartum period disseminated intravascular coagulation occurred, and 9 units of erythrocyte suspension, 4 units of thrombocyte apheresis, and 9 units of fresh frozen plasma were given. She died due to pulmonary embolism and cardiopulmonary arrestat at the postpartum eighth day (Table 1).

Table 1. Presentation and mortality of cases

\begin{tabular}{|l|l|l|}
\hline & Diagnosis & Mortality \\
\hline Case 1 & 18 weeks of gestation & 2 years after abortion \\
\hline Case 2 & 1 year before pregnancy & Postpartum third day \\
\hline Case 3 & 34 weeks of gestation & $\begin{array}{l}\text { Postapartum eighth } \\
\text { day }\end{array}$ \\
\hline
\end{tabular}

\section{DISCUSSION}

Hematologic cancer during pregnancy occurs rarely, however it causes severe maternal and fetal complications. The main purpose of treatment is to protect the mother from the complications of the disease. Therefore, the termination of pregnancy is often reasonable at early gestational ages, but treatment is mostly appropriate at later gestational ages ${ }^{3}$.The rarity of the hematologic malignancies during pregnancy and the similarity of the laboratory abnormalities such as anemia or thrombocytopenia of the disease and pregnancy encompass the retardation in diagnosis that increases the maternal and fetal morbidity and mortality 4,5 . The results and complicated management of hematologic cancer in pregnancy create the need for collaborative approach of a medical team consisting of an oncologist, hematologist, obstetrician, and pediatrician.

The consequence of pregnant women with AML seems to be poorer than that of age-matched nonpregnant women ${ }^{6}$. Due to chemotherapy for the disease, intrauterine growth retardation was reported in some articles, that is compatible with our first case ${ }^{7,8}$. The preterm contractions after cytotoxic 
treatment are one of the main obstetrical problems. If the delivery before 34 weeks of gestational age is unavoidable, then the corticosteroids for fetal lung maturation should be taken into account ${ }^{9}$. In our case with acute lymphoblastic leukemia, the patient did not recognize her uterine contraction reaching a cervical dilatation of $5 \mathrm{~cm}$ hence we had no time for applying the corticosteroids for pulmonary maturity. The incidence of non-Hodgkin's lymphoma may rise, because the pregnancies were planned at later in life and the occurrence of AIDSrelated non-Hodgkin's lymphoma were increased in developing countries ${ }^{10}$. Most of the cases were reported to be aggressive that is compatible with our case with non-Hodgkin's lymphoma ${ }^{11}$, 12 .

\section{REFERENCES}

1. Triunfo S, Scambia G.Cancer in pregnancy: diagnosis, treatment and neonatal outcome. Minerva Ginecol 2014; 66: 325-34.

2. Lavi N, Horowitz NA, Brenner B. An update on the management of hematologic malignancies in pregnancy. Womens Health (Lond Engl) 2014; 10: 255-66.

3. Brenner B, Avivi I, Lishner M. Haematological cancers in pregnancy. Lancet 2012; 379: 580-7.

4. Sadural E, Smith LG Jr. Hematologic malignancies during pregnancy. Clin Obstet Gynecol1995; 38: 535-46.

5. Chandra S, Tripathi AK, Mishra S, Amzarul M, Vaish AK. Physiological changes in hematological parameters during pregnancy. Indian J Hematol Blood Transfus 2012; 28: 144-6.

6. Henig I, Vidal L, Henig O, Benyamini N, Avivi I. Acute Myeloid Leukemia Diagnosed During Pregnancy: Facing Challenges. Systematic Review and Analysis of 174 Reported Cases. Blood 2013; 122: 21.

7. Niedermeier DM, Frei-Lahr DA, Hall PD. Treatment of acute myeloid leukemia during the second and third trimesters of pregnancy.
In conclusion, the hematologic malignancy during pregnancy necessitates a multidisciplinary approach for diagnosis and management of the disease. The psychological, ethical and medical situations should be taken into consideration regarding the gestational age, the stage of disease and the preference of the patient about the pregnancy continuation during the management. Considering the delay in diagnosis or treatment that may cause life-threatening conditions for the pregnant woman, during antenatal care, increased awareness of health workers and pregnant women about clinical features of hematological malignancies can lead to early diagnosis and improved outcome of pregnant women with hematological malignancies.

Pharmacotherapy 2005; 25: 113440.

8. Dilek I, Topcu N, Demir C, Bay A, Uzun K, Gul A, Faik Oner A, Ugras S. Hematological malignancy and pregnancy: a single-institution experience of 21 cases. Clin Lab Haematol 2006; 28: 170-6.

9. Vanderbriele C, Vassou A, Pentheroudakis G, Van Calsteren K, Amant F. Hematologic Malignancies in Pregnancy.http://www.intechopen.c om/books/acute-leukemia-thescientist-s-perspective-andchallenge/hematologicmalignancies-in-pregnancy. Accessed 6 January 2015.

10. Pereg D, Koren G, Lishner M. The treatment of Hodgkin's and nonHodgkin's lymphoma in pregnancy. Haematologica 2007; 92: 1230-7.

11. Spitzer M, Citron M, Ilardi CF, Saxe B. Non-Hodgkin's lymphoma during pregnancy. Gynecol Oncol 1991; 43: 309-12.

12. Gelb AB, van de Rijn M, Warnke RA, Kamel OW. Pregnancyassociated lymphomas. A clinicopathologic study. Cancer 1996; 78: 304-10. 